EREM 72/3

Journal of Environmental Research, Engineering and Management Vol. 72 / No. 3 / 2016

pp. $38-50$

DOI 10.5755/j01.erem.72.3.14716

(c) Kaunas University of Technology
Nitrate Removal from Tile Drainage Water - Laboratory Tests Using Denitrification Bioreactors
Accepted after revision 2016/12

\title{
Nitrate Removal from Tile Drainage Water - Laboratory Tests Using Denitrification Bioreactors
}

\section{Ina Živatkauskienè, Arvydas Povilaitis}

Water Resources Engineering Institute, Aleksandras Stulginskis University

Universiteto 10, LT-53361 Akademija, Kaunas dist., Lithuania

Corresponding author: ina.zivatkauskiene@gmail.com

Ina Živatkauskienè, Water Resources Engineering Institute, Aleksandras Stulginskis University

Universiteto 10, LT-53361 Akademija, Kaunas dist., Lithuania

Tile drainage systems introduced in agricultural areas significantly alter water and nutrient balance and increase water pollution via accelerated nitrates leaching from the soil. In order to reduce this negative effect, new ways and measures to reconstruct tile drainage systems are being searched for. One of the possible solutions of this problem is installation of denitrification bioreactors at the outlets of the systems. Their presence is based on biological removal of nitrate-nitrogen from tile water under anaerobic conditions.

Three denitrification bioreactors imitating tile drainage systems were created in the Drainage Laboratory of the Water Resources Engineering Institute at Aleksandras Stulginskis University, Lithuania. Bioreactor containers were filled with deciduous, coniferous and mixed wood chips. Water of various nitrate-nitrogen concentrations was supplied to the bioreactors from specially equipped tanks creating different flow and water retention conditions in the bioreactors.

Laboratory scale tests show that, during the first three decades (30 days) starting from implementation, biochemical processes stabilise in bioreactors and the most effective nitrate-nitrogen transformations taking place in the water are reached. Then nitrate-nitrogen compounds are rapidly converted into gaseous forms of nitrogen. The 
effectiveness of these transformations largely depends on biological activity (denitrifying bacteria), which is dependent on water temperature, dissolved oxygen amount and water retention time. An experimental study showed that the average nitrate-nitrogen removal from water was $54 \%$ in the bioreactor filled with deciduous wood chips, $60 \%$ in the bioreactor filled with conifer wood chips, and $63 \%$ in the bioreactor filled with mixed wood chip.

The obtained results suggest that denitrification bioreactors can be applied in tile drainage systems as an edge-offield measure to reduce water pollution in drained agricultural areas.

Keywords: agricultural drainage, nitrate-nitrogen, denitrification bioreactors, water quality.

\section{Introduction}

In order to improve the agricultural productivity, in the second half of the last century, too wet soils in Lithuania were intensively drained by various means of agricultural drainage. The drained land area of the country reached 3,021 million ha (47\% of the country area or $87 \%$ of the agricultural land area), and 2,620 million ha of this area was drained by tile drainage systems. In this respect, Lithuania is one of the most extensively drained areas in the world (Povilaitis, 2014). The draining of agricultural areas by means of tile drainage is an effective tool for the removal of excess moisture from the soil, but while entering into drains water leaches various nitrogen compounds $\left(\mathrm{NO}_{3}\right.$ in particular) and other biogenic substances not assimilated by plants (Povilaitis et al., 2015; Lagzdins et al., 2012; Tiemeyer et al., 2006; Gaigalis et al., 2001). The increased inflow of these substances into surface water bodies leads to their eutrophication (Dupas et al., 2014; Novotny, 2003).

According to the assessment of various international environmental organisations (HELCOM, 2013), Lithuania is considered as one of the 'hot spots' in terms of pollution of the Baltic Sea. Therefore, until 2021, the country is obligated to reduce 11.8 thousand tonnes of nitrogen entering into the sea. This is a big challenge that requires new solutions. Research results indicate (Deelstra et al., 2014; Wesström et al., 2007) that the inflow of nitrogen from tile drained agricultural areas is a significant source of this pollution. The solution of the above mentioned problem using purely agronomic or severe economic activity limitation measures often does not reach the expected results due to the diversity of natural factors (e.g. flushy character of rainfall leading to high drainage runoff) and changeable climatic conditions. It is obvious that technological innovations in tile drainage system design and implementation are necessary.
The first attempts to apply biotechnologies for the removal of nitrogen in tile drainage water have been started in the US (Cook et al., 2001). The main idea of these technologies is based on the direct installation of bioreactors into the trenches of tile drainage systems. The performance of bioreactors is driven by denitrification process, which takes place under oxygen limited conditions in a specifically constructed trench filled with organic material where the tile water is diverted. At the same time, the denitrifying bacteria utilise oxygen to process (oxidise) the available carbon and herewith convert nitrates in water into nitrogen gas (Povilaitis et al., 2011; Shaffer et al., 2008; Boyd, 2000):

$4 \mathrm{NO}_{3}+5 \mathrm{C}+\mathrm{H}_{2} \mathrm{O} \rightarrow 2 \mathrm{~N}_{2}+\mathrm{CO}_{2}+4 \mathrm{HCO}_{3}$.

Growth and activity of denitrifying bacteria are directly dependent on environmental factors, such as inflow concentration, amount of dissolved oxygen, $\mathrm{pH}$, water temperature, organic matter content and its structure and water retention time (Christianson et al., 2012; Appleford et al., 2008 ; Wildman, 2001).

According to Lysoviene (2013), microbiological processes are very important for the digestion of chemical compounds in the aqueous medium. Processes going on in denitrification bioreactors are a complex combination of hydrodynamic and biochemical processes.

Limited studies suggest that application of 'nature driven' measures can substantially reduce nitrate-nitrogen $\left(\mathrm{NO}_{3}-\mathrm{N}\right)$ concentrations in drainage water (Christianson et al., 2011; Christianson et al., 2010; Cameron et al., 2010; Moorman et al., 2010; Christianson et al., 2009; Shipper, 2001). In Lithuania, 80\% of diffuse pollution 
comes from agricultural areas (Povilaitis et al., 2014). Therefore, the country has made significant efforts and allocated financial resources to reducing environmental pollution (Povilaitis et al., 2011). The EU Water Framework Directive (2000/60/EC) and the National Environmental Protection Strategy (Valstybès žinios, 2015, XII-1626) provide the fundamental water resources protection policy aiming at reducing water pollution from diffuse and point sources. The EU Baltic Sea Region Strategy (Valstybès žinios, 2012, No. 1264) also serves for the implementation of the action measures aimed at the introduction of newer, less negative impact on aquatic ecosystems friendly technologies, cleaner production techniques and management systems.

Environmental requirements encourage the search for new ways of reconstructing drainage systems. Unfortunately, management of bioreactors and optimisation of denitrification process in drainage systems require extensive laboratory scale and field trials in which the most appropriate characteristics of their introduction under local natural conditions should be determined.
Therefore, the main objective of this research was to determine under laboratory conditions the efficiency of nitrate-nitrogen removal from water and the factors influencing it through denitrification bioreactors with different wood chip fillers.

\section{Methods and procedures}

\section{Installation of bioreactors}

Three rectangular shape (length $130 \mathrm{~cm}$, width $35 \mathrm{~cm}$, height $70 \mathrm{~cm})$ denitrification bioreactors $\left(0.32 \mathrm{~m}^{3}\right.$ volume each) were installed in the Drainage Laboratory of the Water Resources Engineering Institute at Aleksandras Stulginskis University (ASU). For this purpose, three metal containers coated with insulating material on the inside were used. They were connected to two $\left(1.0 \mathrm{~m}^{3}\right.$ volume each) communicating plastic water tanks by flexible hoses. Each bioreactor container was filled with different wood chip fillers. The principal bioreactors installation scheme is shown in Fig. 1.

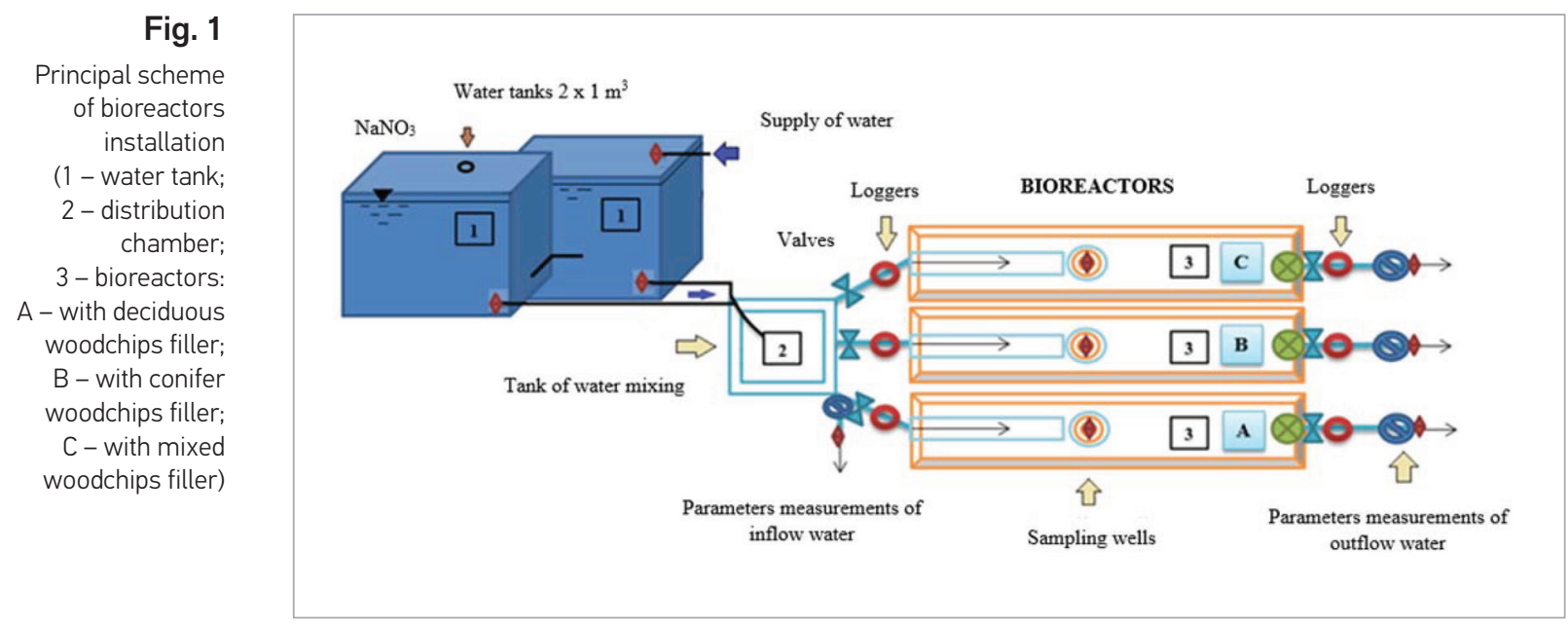

In the Laboratory, the experiment with the bioreactor filled with deciduous tree wood chips (A) lasted from February to November in 2015; the denitrification bioreactor with conifer wood chips filler (B) and the denitrification bioreactor with mixed wood chips filler (C) were tested from June to November in 2015.

Bioreactor fed nitrate-nitrogen concentrations in the water tanks during the study period ranged from 4 to
$15 \mathrm{mg} / \mathrm{L}$. They were typical of the range of $\mathrm{NO}_{3}-\mathrm{N}$ values found in drainage water under field conditions. Water from the tanks into each bioreactor was supplied by gravity. Flow velocity was determined by the difference in the hydraulic head between the water level in the tanks and the bioreactors. The water supply to the bioreactors and the outflow rates were adjusted manually with the help of valves. The control of valves also 
enabled achievement of different water retention times. Before entering the bioreactors, water first got into the water distribution chamber, which was equipped with an additional valve for water flow sampling. Water inflow and outflow from the bioreactor readings were recorded with the help of water loggers. Each bioreactor inside was equipped with additional water sampling wells where the water level was recorded. In all the sampling sites, water temperature, $\mathrm{pH}$, dissolved oxygen and $\mathrm{NO}_{3}-\mathrm{N}$ concentrations were measured. $\mathrm{Ni}-$ trate-nitrogen concentrations were determined by the means of Photometer MD600/MaxDirect system, using a powder-like consistency reagent Vario Powder Pack. The dissolved oxygen amount was measured with a portable Eijkelkamp 18.28 oxygen meter, and the $\mathrm{pH}$ values were measured by the portable WTW pH340i device. Inflow, outflow and inside bioreactor water temperatures were measured by the multifunctional portable system WTW Multi 350i.

\section{Determination of physical characteristics of wood chips}

Bioreactor tanks were filled with wood chips made from local raw materials - deciduous and coniferous tree of- fal. The use of wood chips in bioreactors allows heterotrophic denitrifying bacteria to develop. Bacteria need organic material as a carbon source; therefore, a biofilm on the surface of wood chips is formed.

Wood chip size and mass porosity are important physical parameters to determine water volume and water retention time in bioreactors.

Thus, the percentage distribution of the size of wood chips in the single mass was determined by sieving them with different sized sieves.

The distribution of deciduous tree wood chips was as follows (see Fig. 2 (A)): $<1.0 \mathrm{~cm}-41 \%$, from 1.1 to $2.0 \mathrm{~cm}-51 \%$, from 2.1 to $3.0 \mathrm{~cm}-4 \%$, from 3.1 to $4.5-3 \%$, and $>4.5 \mathrm{~cm}-1 \%$.

The distribution of coniferous tree wood chips according to their particle size was as follows (see Fig. 2 (B)): $<1.0 \mathrm{~cm}-10 \%$, from 1.1 to $2.0 \mathrm{~cm}-24 \%$, from 2.1 to $3.0 \mathrm{~cm}-34 \%$, from 3.1 to $4.5-20 \%$, and $>4.5 \mathrm{~cm}-12 \%$.

The distribution of mixed wood chips according to their size was as follows (see Fig. 2 (C)): $<1 \mathrm{~cm}-27 \%$, from 1.1 to $2.0 \mathrm{~cm}-41 \%$, from 2.1 to $3.0 \mathrm{~cm}-15 \%$, from 3.1 to $4.5-9 \%$, and $>4.5 \mathrm{~cm}-8 \%$.

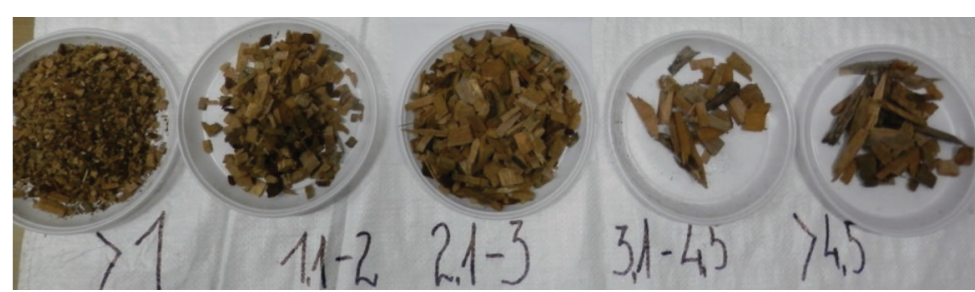

A
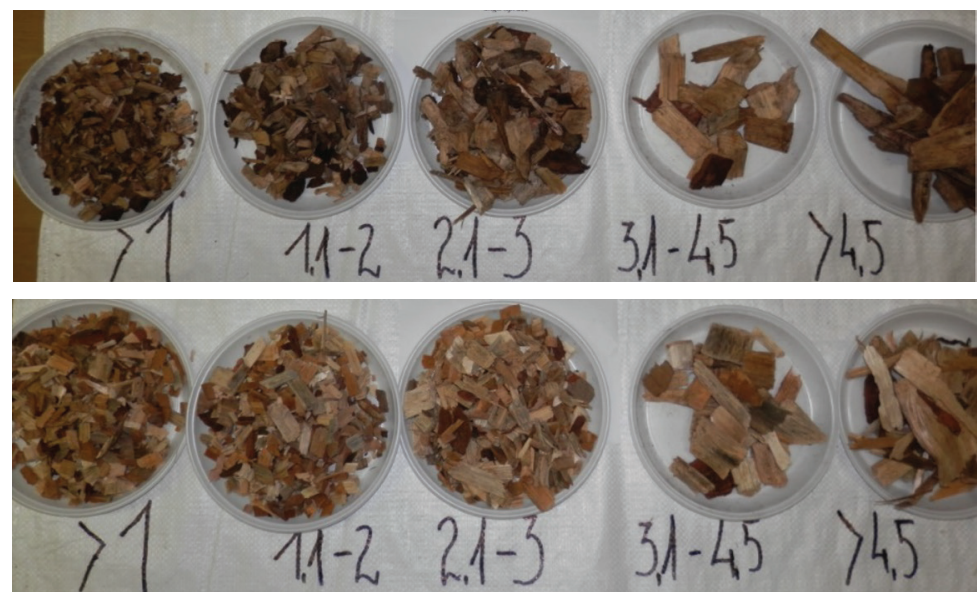

Fig. 2

Distribution of wood chips according to their size (A - deciduous; $B$ - coniferous; C-mixed) 
From the characteristic textures and colours of wood chips, it was found that alder dominated in deciduous wood chips, spruce dominated in coniferous wood chips and pine trees dominated in mixed wood chips.

Wood chip porosity was determined using the standard porosity determination procedure described by Christianson et al. (2010).

The chips were placed into a container of the known volume and filled with water up to the top of the container. Covered with polyethylene blanket (to prevent water evaporation), the container was kept for 24 hours. After 24 hours, part of the water was absorbed by wood chips. In order to provide uniform impregnation of chips, the water content in the container was constantly supplemented. When the water level in the container remained constant and coincided with the water saturation boundary in wood chips (this happens after approximately 48 hours), the water was poured off and its volume was measured. Subsequently, wood chip mass porosity was determined according to the formula:

$$
p=\frac{V_{p}}{V_{b}} * 100
$$

where

$p$ - wood chip porosity (\%), $V_{p}$ - water volume with wood chips (l); $V_{b}$ - container volume (l).

The analysis revealed that coniferous wood chip porosity was $54 \%$, deciduous tree wood chip porosity was $53 \%$, and mixed tree wood chip porosity was $53 \%$.

\section{Determination of other characteristics}

Hydraulic conditions may have a direct effect on the $\mathrm{NO}_{3}$ removal efficiency in bioreactors. The most important of them is the calculated quantity expressing the mean time that water spends in a bioreactor, i.e. water retention time. This parameter was calculated according to equation 3 , and water discharge was calculated according to equation 4 :

$$
\tau=\frac{\rho V}{Q}
$$

where

$\tau$-water retention time (hour), $\rho$ - porosity of wood chips, $V$ - bioreactor volume $\left(\mathrm{m}^{3}\right), \mathrm{Q}$ - water discharge $\left(\mathrm{m}^{3} /\right.$ hour$)$.

$$
Q=\frac{S k_{2}-S k_{1}}{\Delta T}
$$

where

$Q$ - water discharge ( $\mathrm{m}^{3} /$ hour); $S k_{1}$ - water volume (meter readings) at inflow $\left(\mathrm{m}^{3}\right) ; S k_{2}$ - water volume (logger readings) at outflow $\left(\mathrm{m}^{3}\right) ; \Delta T$ - time step (hour).

The experimental tests first were started with the bioreactor loaded with deciduous wood chips (A). Water supply velocity into this bioreactor ranged from 1.95 to $173.55 \mathrm{~L} / \mathrm{h}$, while into bioreactor (B) from 2.17 to $161.13 \mathrm{~L} / \mathrm{h}$, and into bioreactor (C) from 2.11 to $152.31 \mathrm{~L} / \mathrm{h}$.

Water supply rates were relatively consistent with those measured under the field conditions.

For example, the average daily flow rate at the outlet of 13.6 ha tile drainage system in Kaunas MIS experimental station ranged from 3.6 to $136.8 \mathrm{~L} / \mathrm{h}$ for the period between 1967 and 1985 (Sakalauskas, 1990).

During the experiment, the water samples were taken at irregular time steps according to water supply and water retention time characteristics.

The nitrate-nitrogen concentrations were determined in the inflow water, in the water of sampling wells and in the outflow.

Variation of measured parameter values allowed presuming the ongoing nitrogen transformations in the bioreactors.

Nitrate-nitrogen removal efficiency in the bioreactors was calculated according to the equation:

$$
E=\frac{C_{i n\left(N \mathrm{NO}_{3}-N\right)}-C_{\text {out }\left(\mathrm{NO} \mathrm{O}_{3}-N\right)}}{C_{i n\left(N \mathrm{NO}_{3}-\mathrm{N}\right)}} * 100
$$

where

E- nitrate-nitrogen removal efficiency (\%),

$C_{i n\left(N O_{3}-N\right)}$ - nitrate-nitrogen inflow concentration $(\mathrm{mg} / \mathrm{L})$,

$\mathrm{C}_{\text {out }\left(\mathrm{NO}_{3}-\mathrm{N}\right)}$ - nitrate-nitrogen outflow concentration $(\mathrm{mg} / \mathrm{L})$.

The comparison of the efficiency of nitrogen removal in different bioreactors was done based on the average removal rates during the analysed periods. 


\section{Results}

The obtained results indicate that soaked wood chips facilitate reduction of oxygen and further nitrate transformations in bioreactors. The observed dynamics (Fig. 3) of dissolved oxygen concentrations suggest that oxygen deficiency conditions are established and the balance of anaerobic environment stabilises in there. The drop-off in the dissolved oxygen amount confirms that it is actively consumed by heterotrophic microorganisms. The data show that the amount of oxygen consumed by respiration reaches the maximum (when the dissolved oxygen amount ranges from 0.00 to $0.50 \mathrm{mg} / \mathrm{L}$ ) during the first 10 days of the start-up of the reactor.

Graphs A, B and C in Fig. 3 reveal that the dissolved oxygen concentration in inflowing water ranges between 9.35 and $4.10 \mathrm{mg} / \mathrm{L}$. However, the actual concentration of dissolved oxygen in the bioreactors themselves is significantly reduced and varies from 5.30 to $0.00 \mathrm{mg} / \mathrm{L}$. The research tests demonstrated that at the bottom layer of the bioreactors (approximately $20 \mathrm{~cm}$ above the container's bottom) anaerobic conditions formed during 2-3 hours after the start of inflow.

Test graph A presented in Fig. 3 is clearly different from test graphs $B$ and $C$. These differences are related to the fact that bioreactor $A$ with a deciduous wood chip filler was used first for the experimental testing. During the testing, some technological problems appeared and were gradually fixed. In fact, microbiological activity and decomposing organic matter shreds clogged the filter material at the outlet. Come to light, the filter fabric with a very small mesh size (commonly used as a filter envelope on tile drain pipes) cannot be used in bioreactors. Therefore, the recommended filter fabric's mesh should be at least $3 \mathrm{~mm} \times 3 \mathrm{~mm}$ size.

After the removal of the difficulties (127 days from reactor A start-up and the introduction of reactors B and C), the temporal pattern of the dissolved oxygen concentrations in all the bioreactors became similar.

Under oxygen deficiency conditions and the availability of $\mathrm{NO}_{3}$, microorganisms transform nitrates into gaseous nitrogen forms. Unfortunately, it was not possible to determine nitrogen gas emissions in this study due to the lack of suitable measuring equipment. Never- theless, the differences in nitrate concentrations at inlet and outlet clearly demonstrate (Fig. 4 ) that this process was intense. Nitrate concentrations ranged from 6.00 to $60.00 \mathrm{mg} / \mathrm{L}$ in the inflowing water and from 4.00 to $51.00 \mathrm{mg} / \mathrm{L}$ in the outflow. It should be noted that nitrogen removal efficiency was dependent on nitrogen concentration in the inflow. The decrease in nitrogen concentration reduction is shown in Fig. 4 (tests A, B and C). It is obvious that biological nitrogen removal was going on in all the bioreactors.

The nitrate removal efficiency over time is revealed particularly well by applying cumulative curves (Fig. 5). The analysis of the data of the bioreactor with deciduous tree wood chips (A) demonstrated that after 331 days since its release the total nitrate-nitrogen inflow mass was $69.05 \mathrm{~g}$, while $31.75 \mathrm{~g}$ was retained in the bioreactor. The reduction of the nitrate-nitrogen mass in it reached $54 \%$ compared with the total amount observed in the inflow. During the analysed period, $12.42 \mathrm{~m}^{3}$ of water passed through reactor $A$. In the cumulative curve (graph A), it can be seen that in the first three months the difference in the inflow and outflow content of $\mathrm{NO}_{3}-\mathrm{N}$ was stable and varied little.

After 121 days from the start-up, the differences of the $\mathrm{NO}_{3}-\mathrm{N}$ mass content began to grow intensively. This indicates that bioreactors require adequate time (in this case about 2 months) for effective removal of nitrogen. It is believed that such a period is necessary for the formation of an active biocenosis and optimal conditions for denitrification to take place.

In the denitrification bioreactor with the conifer wood chip filler (B), $15.77 \mathrm{~g}$ of nitrate-nitrogen were removed within 117 days. This corresponds to $60 \%$ of the inflowing amount of nitrate-nitrogen. During the period, $8.26 \mathrm{~m}^{3}$ of water passed through the reactor. Over the same period in the denitrification bioreactor with mixed wood chip filler (C), $9.01 \mathrm{~g}$ of nitrate-nitrogen were removed, which makes up to $63 \%$ of the total inflow amount of the nitrate-nitrogen content.

The nitrate-nitrogen removal rates by event were calculated from the total amount of $\mathrm{NO}_{3}-\mathrm{N}$ removed during an event divided by reactor volume filling with water and event step. The research tests revealed that the average nitrate removal rate in bioreactor $A$ was $0.64 \mathrm{~g} / \mathrm{m}^{3} / \mathrm{h}$. It ranged from 0.02 to $2.42 \mathrm{~g} / \mathrm{m}^{3} / \mathrm{h}$. 
Fig. 3

The dissolved oxygen concentration changes in denitrification bioreactors with different wood chip (A, B and C) fillers. (Legend: Inflow concentration in the inflow; Outflow concentration in the outflow; Well concentration in the well)
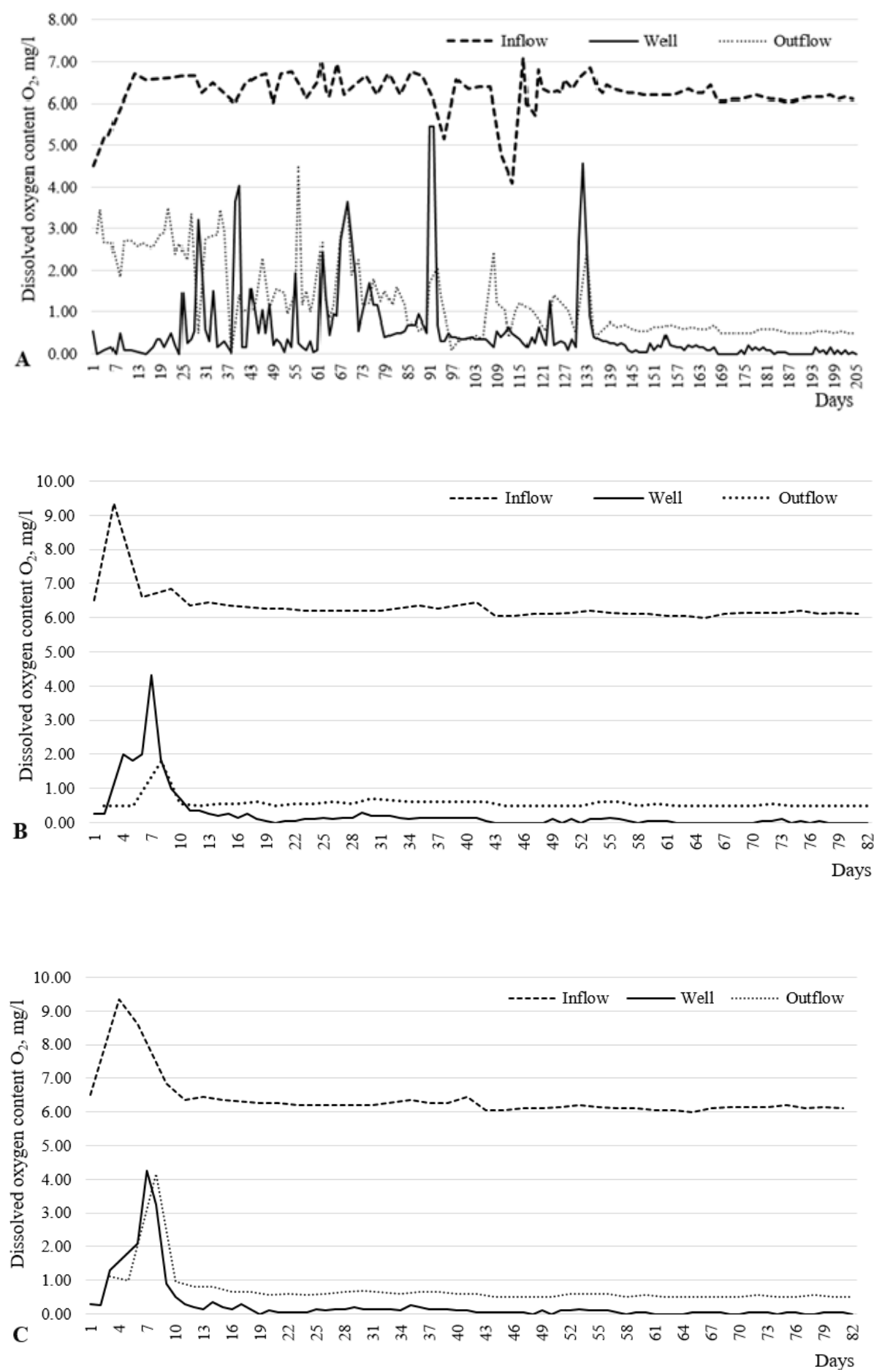


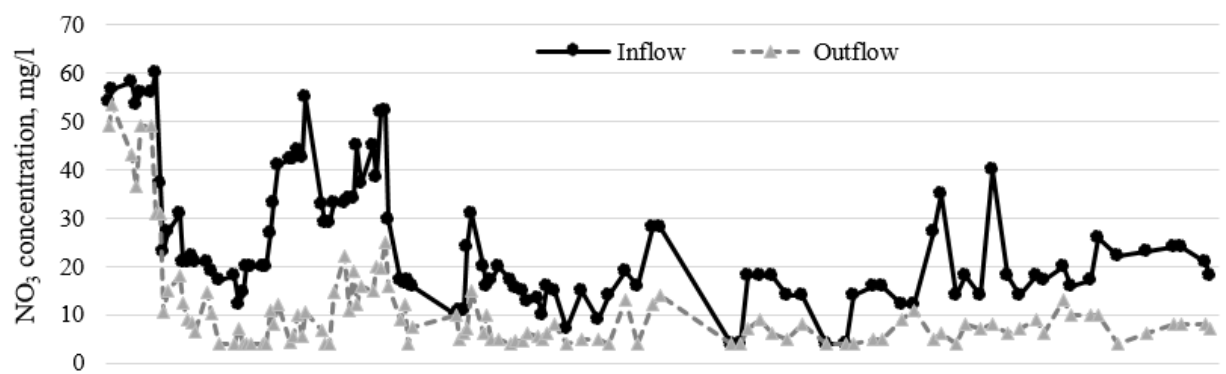

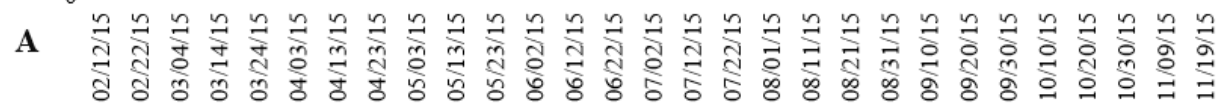

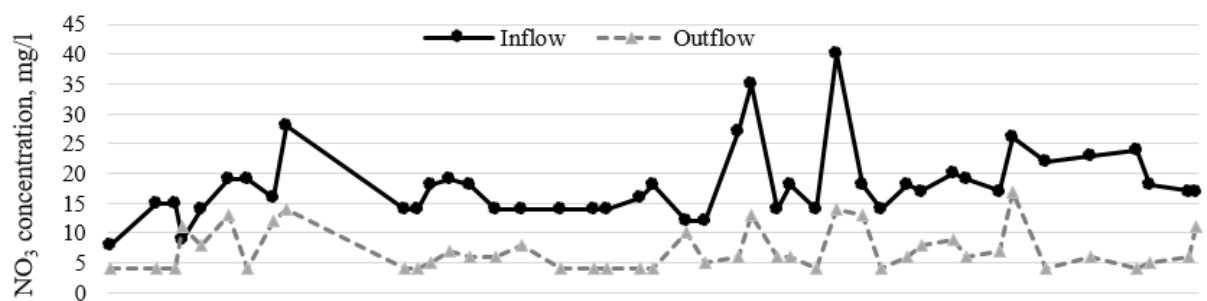

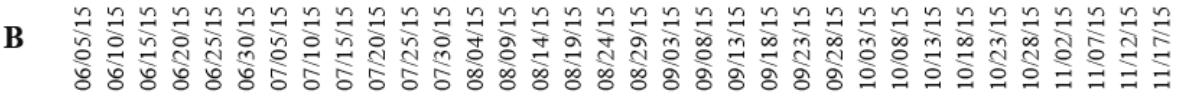

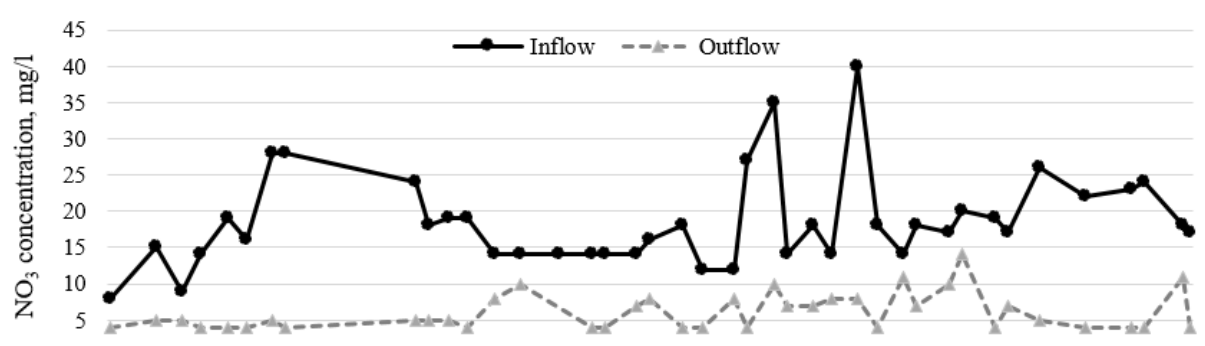

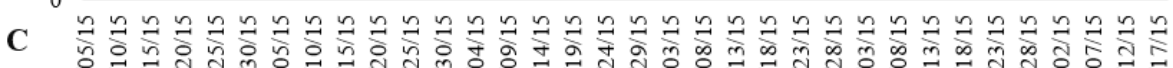

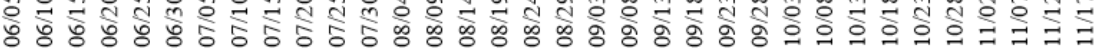


Fig. 5

Cumulative nitratenitrogen retention curves in the bioreactors with different wood chip (A, B and C) fillers. (Legend: Inflow volume of inflowing nitrate-nitrogen; Outflow - volume of outflowing nitrate-nitrogen; Total - total volume of water delivered)

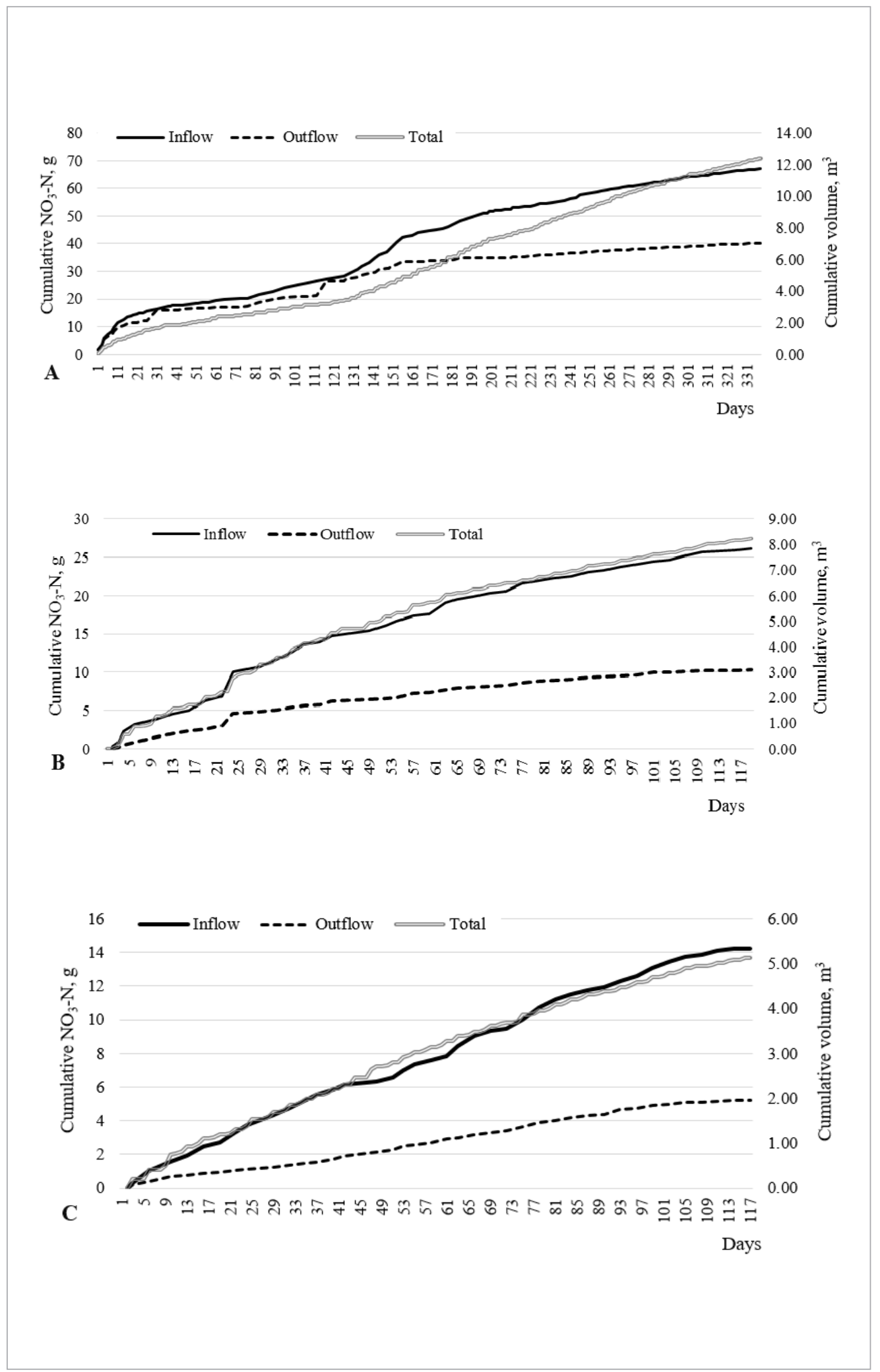




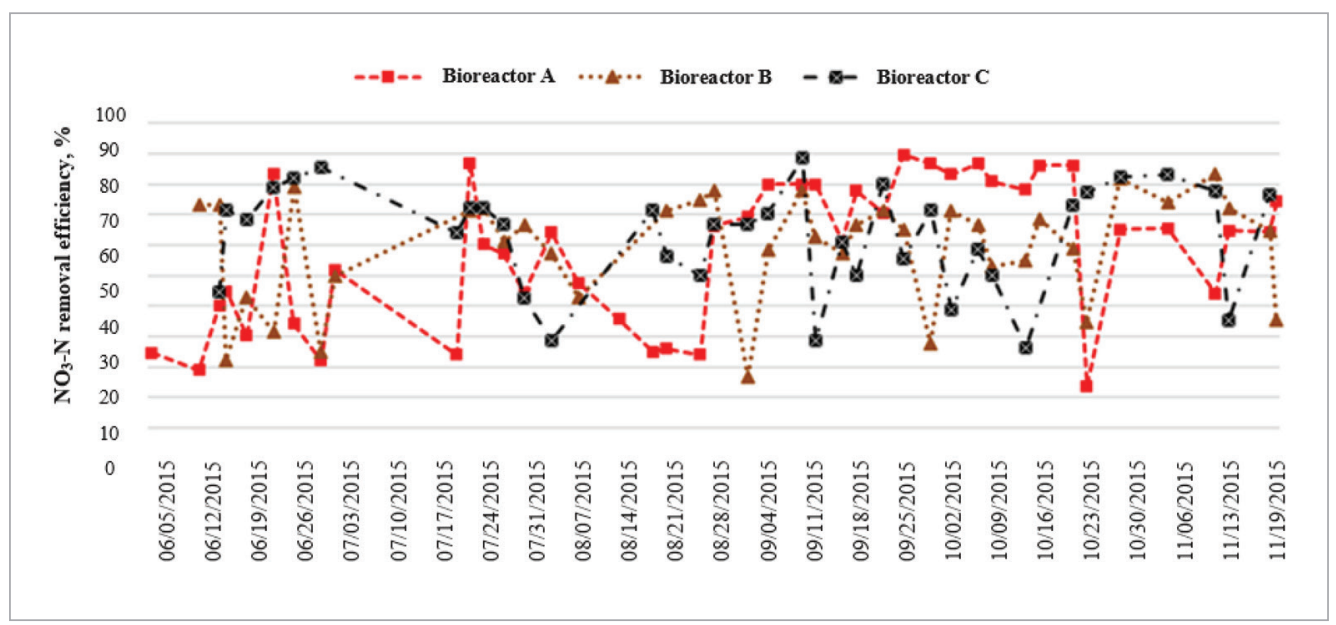

Fig. 6

Dynamics of nitrate-nitrogen removal efficiency in bioreactors with different fillers during the measurement period
In bioreactor $\mathrm{B}$, the average removal rate was $0.46 \mathrm{~g} /$ $\mathrm{m}^{3} / \mathrm{h}$, and it varied from 0.16 to $1.22 \mathrm{~g} / \mathrm{m}^{3} / \mathrm{h}$. In bioreactor $\mathrm{C}$, the average removal was $0.33 \mathrm{~g} / \mathrm{m}^{3} / \mathrm{h}$, and it varied from 0.04 to $1.25 \mathrm{~g} / \mathrm{m}^{3} / \mathrm{h}$. The nitrate removal rate differences appeared due to the difference in bioreactor volume filling with water and the water retention time within which the biochemical degradation of nitrogen compounds occurs.

In comparison, the results indicate that nitrate-nitrogen removal per $1 \mathrm{~m}^{3}$ of water was approximately $2.1 \mathrm{~g}$ in bioreactor $\mathrm{A}$ it, up to $1.9 \mathrm{~g}$ in bioreactor $\mathrm{B}$, and up to $1.8 \mathrm{~g}$ in bioreactor $\mathrm{C}$. The average count of $\mathrm{NO}_{3}-\mathrm{N}$ removal rates in bioreactor $\mathrm{A}$ was slightly higher due to the difference in the event length (i.e. 331 days in bioreactor $A$ and 117 days in bioreactors $B$ and $C$ ).

The analysis of the laboratory scale tests revealed that the time period of 21 days, shown in the cumulative curve of $\mathrm{NO}_{3}-\mathrm{N}$ (Fig. 5, B and C), counting from the reactor start-up, was characterized by much stable dynamics of nitrate-nitrogen removal.

After analysing and summarising the results of the research, it could be stated (see graphical dynamics in Fig. 6) that there is no significant difference in terms of the average nitrogen removal efficiency between the bioreactors with conifer and mixed wood chip fillers. However, the efficiency of nitrogen removal in the bioreactor with deciduous tree wood chips is slightly lower.

More detailed statistical analysis on the significance of differences among the bioreactors was not performed. This is going to be done when more data are avail- able. Nevertheless, the conducted tests revealed that the average $\mathrm{NO}_{3}-\mathrm{N}$ removal efficiency in the bioreactor with deciduous tree wood chips (A) was $54 \%$, with conifer wood chips (B) $60 \%$, and with mixed wood chips (C) $63 \%$.

\section{Discussion}

The study revealed that denitrification bioreactors could be an effective tool for removing nitrate-nitrogen from drainage water. It is obvious that not only an active biocenosis but the hydraulic flow conditions as well are important for such a nitrate-nitrogen removal technique. In order to keep up with microorganisms to consume oxygen and quickly transform nitrate-nitrogen compounds into gaseous nitrogen forms and change the nitrogen cycle in water, adequate water retention time in bioreactors must be ensured. Different water retention characteristics of bioreactors can be achieved by adjusting water inflow and outflow.

The water retention time in denitrification bioreactor A during the study period ranged from 1 up to 188 hours. Under the proper conditions (water temperature $13-15^{\circ} \mathrm{C}$, dissolved oxygen concentration in water $0.0 \mathrm{mg} / \mathrm{L}$, and prevalence of a neutral or slightly alkaline aqueous medium), the nitrate-nitrogen removal efficiency in the bioreactor could reach $35 \%$ within 1.0 hour as water retention time. In bioreactors $B$ and $C$, the water retention time ranged from 1 up to 169 hours. Under the above-mentioned conditions, after the retention 
of water flow for 1 hour, the nitrate-nitrogen removal efficiency in bioreactor (B) was 23\%; and under similar conditions in bioreactor $\mathrm{C}, 38 \%$. It was found that the removal efficiency of nitrate-nitrogen (up to $50 \%$ ) could be achieved when water retention time is not less than 1 hour.

Christianson et al. (2013) and Cameron et al. (2010) also report that there is a linear dependence between the efficiency of nitrate removal and water retention time, i.e. with the increase in water retention time the nitrate removal efficiency increases as well.

According to these studies, when the retention time in bioreactors varies from 4 to 8 hours the nitrate-nitrogen removal efficiency may range between $30 \%$ and $70 \%$. Unfortunately, for the determination of the dependence of water retention time and nitrate-nitrogen removal in bioreactors, further detailed studies not only under the laboratory scale but also under field conditions are necessary. Such a type of experiments has only recently been started at ASU; therefore, more reliable results and statistical analyses are not available yet. This research study is the first attempt to test the applicability of bioreactors for the $\mathrm{NO}_{3}$ removal in tile drainage systems in Lithuania.

Only on the basis of both laboratory and field scale measurements, bioreactor design characteristics for their installation in drainage systems will be determined.

\section{References}

Appleford J.M., Rodriguez L.F., Cooker R.A., Zhang Y., Kent A.D., and Zilles J. (2008) Characterization of microorganisms contributing to denitrification in tile drain biofilters in Illinois". In: Proccedings of the ASABE Annual International Meeting, Providence, pp. 54-63. Boyd E.C. (2000) Water Quality", Auburn University, USA. pp. 175-174

Cameron S.G., and Schipper L.A. (2010) Nitrate removal and hydraulic performance of organic carbon for use in denitrification beds". Ecological Engineering 36 (11):1588-1595. https:// doi.org/10.1016/j.ecoleng.2010.03.010

Christianson L., Helmers M., Bhandari A. and Moorman T. (2013) Internal hydraulics of an agricultural drainage denitrification bioreactor". Ecological Engineering. 52 (2013):298-307. https://doi.org/10.1016/j.ecoleng.2012.11.001

\section{Conclusions}

1 The laboratory scale tests revealed that during the analysed period of 331 days in the bioreactor with deciduous wood chips the reduction of nitrate-nitrogen mass by $54 \%$ was reached compared with the total amount observed in the inflow mass. During the analysed period of 117 days, the reduction of nitrate-nitrogen mass was also reached in the bioreactor with conifer wood chips (60\%) and with a mixed wood chip filler (63\%).

2 The results of nitrate-nitrogen removal per $1 \mathrm{~m}^{3}$ of through-flowing water revealed that it was approximately $2.1 \mathrm{~g}$ in the bioreactor with deciduous tree wood chips, up to $1.9 \mathrm{~g}$ in the bioreactor with a conifer wood chip filler and up to $1.8 \mathrm{~g}$ in the bioreactor with a mixed woodchips filler. The nitrate removal differences appeared due to the difference in water retention time within which the biochemical degradation of nitrogen compounds occurs.

According to the experimental study results, there was no significant difference between the efficiency of the three types of wood chips used in the bioreactors while removing nitrates. The test results also suggest that denitrification bioreactors can be applied in tile drainage systems for removing nitrate-nitrogen.

Christianson L., Bhandari A. and Helmers M. (2012). A Practice oriented Review of Woodchip Bioreactors for Subsurface Agricutural". Agricultaral and Biosystems Engineering 28(6):861874. Christianson L., Castello A., L. Christianson R., Helmers M. (2010) Hydraulic property determination of denitrifying bioreactor fill media". Agricultaral and Biosystems Engineering. 26(5):849-854.

Christianson L., Bhandari A., and Helmers M. (2011) Pilot-Scale Evaluation of Denitrification Drainage Bioreactors: Reactor Geometry and Performance". Environmental Engineering 137 (2011):213-220. https://doi.org/10.1061/(ASCE) EE.1943-7870.0000316

Christianson L., Bhandari A., Helmers M. (2009) Emerging technology: Denitrification bioreactors for nitrate reduce in ag- 
ricultural water." Soil and Water Conservation. 64(5):139-141. https://doi.org/10.2489/jswc.64.5.139A

Cook R.A., Doheny A.M., Hirschi M.C. (2001) Bioreactors for edge of field treatment of tile outflow". Water Research 35(2001):2654-2668.

Deelstra J., lital A., Povilaitis A., Kyllmar K., Greipsland I., Blicher-Mathiesen G., Jansons V., Koskiaho J., and Lagzdins A. (2014) Hydrological pathways and nitrogen runoff in agricultural dominated catchments". Agricuture, Ecosystems and Environment. 198(2014):65-73. https://doi.org/10.1016/j. agee.2014.06.032

Gaigalis K., Račkauskaite A. (2001) Azoto ir fosforo išplovimo agroekosistemose ypatumai". [Peculiarities of nitrogen and phosphorus leaching in agro-ecosystems]. Vandens ūkio inžinerija 16 (38):39-46.

Lagzdins A., JansonV., Sudars R., and Abramenko K. (2012) Scale issues for assessment of nutrient leaching from agricultural land in Latvia". Hydrology Research. 43(2012):383399. https://doi.org/10.2166/nh.2012.122

Lysovienè J. (2013) Tarša veikiamu vidurio Lietuvos reguliuotu upelių savaiminis apsivalymas sausmečio laikotarpiu". [Self-purification in pollution-exposed regulated streams in middle Lithuania during low flow regime periods]. Daktaro disertacija. Kaunas. P. 12-18.

Moorman T., Parkin T.C., Kaspar T.C., and Jaynes D.B. (2010) Denitrification activity, wood loss, and N2O emisions over 9 years from a wood chip bioreactor". Ecological Engineering 36(2010):1567-1574. https://doi.org/10.1016/j.ecoleng.2010.03.012
Tiemeyer B., Kahle P., Lennartz B. (2006) Nutrient losses from artificially drained catchments in North-Eastern Germany at different scales". Agriculture and Water Management 85(2006):47-57. https://doi.org/10.1016/j.agwat.2006.03.016

Povilaitis Arvydas. (2015). Hydrological effect of artificial drainage in lowland river catchments in Lithuania. Environmental Engineering and Management Journal. Accepted. Vol.14, No.3.

Povilaitis A., Šileika A., Deelstra J., Gaigalis K., Baigys G. (2014) Nitrogen losses from small agricultural catchments in Lithuania". Agricuture, Ecosystems and Environment xx(2014):1-4. https://doi.org/10.1016/j.agee.2014.02.002

Povilaitis A.,Taminskas J., Gulbinas Z., Linkevičienè R., Pileckas M. (2011) Lietuvos šlapynès ir ju vandensauginè reikšmè" [Lithuanian wetland and their protective importance], monografija. Vilnius. pp. 87-111.

Shipper L.A.,Vojvodic-Vokuvic M. (2001) Five years of nitrate removal, denitrification and carbon dynamics in a denitrification wall". Water Research 35(2001):3473-3477. https://doi. org/10.1016/S0043-1354(01)00052-5

Sakalauskas A. (1990) Hidrologijos metraštis (1968-1985).

Wesström I., Messing I. (2007) Effects of controlled drainage on $\mathrm{N}$ and $\mathrm{P}$ losses and $\mathrm{N}$ Dynamics in loamy and with spring crops". Agricultural and Watermanagement 3(87):229-240. https://doi.org/10.1016/j.agwat.2006.07.005

Wildman T.A. (2001) Design of field-scale bioreactors for bioremediation of nitrate in tile drainage effluent". Water Research 34(2001):2232-2242. 


\section{Nitratų šalinimas iš drenžo vandens - laboratorinis tyrimas naudojant denitrifikacijos bioreaktorius}

$2016 \mathrm{~m}$. balandis

Priimta spaudai: 2016 m. gruodis

\section{Ina Živatkauskienė, Arvydas Povilaitis}

Vandens išteklių inžinerijos institutas, Vandens ūkio ir žemètvarkos fakultetas Aleksandro Stulginskio Universitetas, Kaunas, Lietuva

Žemès ūkio plotuose įrengtos drenažo sistemos ženkliai padidina azoto junginių išplovą iš dirvožemio ir paviršiniu vandenu taršą. Siekiant sumažinti ši neigiamą poveiki ieškoma nauju būdu ir priemoniu kaip pertvarkyti drenažo sistemas. Vienas iš galimu šios problemos sprendimo būdu - drenažo sistemose irengti denitrifikacijos bioreaktorius. Ju veikimas gristas biologiniu nitratinio azoto šalinimu iš drenažo vandens keičiant azoto ciklą anaerobinèmis sąlygomis.

Aleksandro Stulginskio universiteto Vandens išteklių inžinerijos instituto sausinimo laboratorijoje buvo sukurti trys drenažo sistemy funkcijas imituojantys denitrifikacijos bioreaktoriai. Bioreaktoriu talpos užpildytos skirtingomis fizikinemis charakteristikomis pasižyminčiomis lapuočiu ir spygliuočiu medžiu skiedromis. Ivairių nitratinio azoto koncentraciju vanduo i bioreaktorius buvo tiekimas iš specialiai įrengtu rezervuaru sukuriant skirtingas tékmès ir vandens sulaikymo bioreaktoriuose sąlygas.

Laboratorinių tyrimu metu nustatyta, kad per pirmas tris dekadas (per 30 dienų) nuo vandens paleidimo bioreaktoriuose nusistovi biocheminiu procesu pusiausvyra ir susiformuoja efektyviausios nitratinio azoto transformacijoms vandenyje vykti sąlygos. Tuomet nitratinio azoto junginiai sparčiausiai verčiami i dujinę azoto formą. Šiu transformaciju greitis priklauso nuo mikroorganizmu (denitrifikatorių) veiklos, kurią sąlygoja vandens temperatūros, ištirpusio deguonies kiekio bei vandens sulaikymo laiko bioreaktoriuose charakteristikos. Eksperimentiniai tyrimai parodè, kad vidutinis nitratinio azoto pašalinimo iš vandens efektyvumas bioreaktoriuje su lapuočių medžiu skiedru užpildu sieke 54 proc., su spygliuočių medžių skiedru užpilu - 60 proc., o su sumaišytu medžių skiedrų užpildu - 63 proc. Šie rezultatai leidžia teigti, kad denitrifikacijos bioreaktoriai gali būti ̨̧rengiami ir žemės ūkio plotuose drenažu tekančiam vandeniui valyti.

Raktiniai žodžiai: ž.ū. drenažas, azoto tarša, denitrifikacijos bioreaktoriai, vandens kokybè. 